\title{
Customer awareness about SEBI Investor Protection Act, 1992: A case study among Vizianagaram Srikakulam and Visakhapatnam Districts
}

\author{
${ }^{1}$ Srinu Madem, ${ }^{2}$ Prof. P Srinivas Subbarao \\ ${ }^{I}$ Asst. Professor, Vignan's Institute Of Information Technology, Visakhapatnam \\ ${ }^{2}$ Professor, Vignan University, Guntur
}

\begin{abstract}
Indian economy is recognised as the most reliable one for investments in different avenues due to its strong judiciary system. Investor protection is important for any investment. Otherwise no market can sustain and grow. Securities and Exchange Board of India is a market regulator of India as we know and one of its objectives is to educate and protect the investors. Also SEBI is recognised as the most respected regulator among the regulators in India. Since 1992, SEBI as an autonomous body making rules and regulations and revising them as per the changing market dynamics and protecting investors restlessly till now. Despite of all its efforts, there are some gaps between investor protection and investor satisfaction. Through our study among three districts (Vizianagaram, Srikakulam and Visakhapatnam) we have tried to unhide the facts about investor satisfaction against protection.
\end{abstract}

\section{Introduction}

Investors are back bone for any economy. Unless and until he/she exploited, industry will be good and performance of economy will be well. But unfortunately, investors have been exploiting in India for various reasons.

The Securities and Exchange Board of India Act, 1992 (the SEBI Act) is an Indian legislation enacted by the Parliament of India for regulation and development of securities market in India. It was amended in the years 1995, 1999 and 2002 to meet the requirements of changing needs of the securities market. The Preamble of the Securities and Exchange Board of India describes the basic functions of the Securities and Exchange Board of India as"...to protect the interests of investors in securities and to promote the development of, and to regulate the securities market and for matters connected therewith or incidental thereto".

Though SEBI has enacted an act to protect the investor, it is not up to the level of investor satisfaction. In this context we have identified a gap between investor protection guidelines and investor grievances. The present study is to know the customer awareness about investor protection Act and also investor satisfaction against protection.

\section{SEBI- Genesis:}

- $\quad$ SEBI is the regulator for the Securities Market in India.

- In 1988 SEBI was established by the Government of India through an executive resolution, and was subsequently upgraded as a fully autonomous body (a statutory Board) in the year 1992 with the passing of the Securities and Exchange Board of India Act (SEBI Act) on 30th January 1992.

- The SEBI was established on April 12, 1992.

\section{SEBI- Basic objectives:}

- To protect the interests of investors in securities.

- To promote the development of Securities Market.

- To regulate the securities market.

- For matters connected therewith or incidental thereto.

\section{SEBI- Major Contributions:}

- Since its inception, SEBI has been working targeting the securities and is attending to the fulfillment of its objectives with commendable zeal and dexterity.

- The improvements in the securities markets like capitalization requirements, margining, establishment of clearing corporations, Demat, etc. reduced the risk of credit and also reduced the market risk.

- SEBI has introduced the comprehensive regulatory measures, prescribed registration norms, the eligibility criteria, the code of obligations and the code of conduct for different intermediaries like, bankers to issue, 
merchant bankers, brokers and sub-brokers, registrars, portfolio managers, credit rating agencies, underwriters and others.

- It has framed bye-laws, risk identification and risk management systems for Clearing houses of stock exchanges, surveillance system etc. which has made dealing in securities both safe and transparent to the end investor.

- Another significant event is the approval of trading in stock indices (like S\&P CNX Nifty \& Sensex) in 2000.

- A market Index is a convenient and effective product because of the following reasons:

- It acts as a barometer for market behavior;

- It is used to benchmark portfolio performance;

- It is used in derivative instruments like index futures and Index options

- Two broad approaches of SEBI is to integrate the securities market at the national level, and also to diversify the trading products, so that there is an increase in number of traders including banks, financial institutions, insurance companies, mutual funds, primary dealers etc. to transact through the Exchanges.

- In this context the introduction of derivatives trading through Indian Stock Exchanges permitted by SEBI in 2000 is a real landmark.

- SEBI has enjoyed success as a regulator by pushing systemic reforms aggressively and successively (e.g. the quick movement towards making the markets electronic and paperless rolling settlement on $\mathrm{T}+2$ basis

\section{Powers and Functions of SEBI:}

- Regulating the business in stock exchanges and any other securities markets.

- Registering and regulating the working of stock brokers, sub-brokers, share transfer agents, bankers to an issue, trustees of trust deeds, registrars to an issue, merchant bankers, underwriters, portfolio managers, investment advisers and such other intermediaries who may be associated with securities markets in any manner.

- Registering and regulating the working of the depositories, custodians of securities, foreign institutional investors, credit rating agencies and such other intermediaries as the Board may, by notification, specify in this behalf.

- Registering and regulating the working of venture capital funds and including mutual funds.

- Promoting and regulating self-regulatory organizations.

- Prohibiting fraudulent and unfair trade practices relating to securities markets.

- Promoting investors' education and training of intermediaries of securities markets.

- Prohibiting insider trading in securities.

- Regulating substantial acquisition of shares and take-over of companies.

- Calling for information from, undertaking inspection, conducting inquiries and audits of the stock exchanges, mutual funds, other persons associated with the securities market intermediaries and selfregulatory organizations in the securities market.

- Calling for information and record from any bank or any other authority or board or corporation established or constituted by or under any Central, State or Provincial Act in respect of any transaction in securities which is under investigation or inquiry by the Board.]

- Performing such functions and exercising such powers under the provisions of the Act as may be delegated to it by the Central Government from time to time.

- Levying fees or other charges for carrying out the purposes of this section.

- Conducting research for the above purposes.

- Calling from or furnishing to any such agencies, as may be specified by the Board, such information as may be considered necessary by it for the efficient discharge of its functions.

- The Board may take measures to undertake inspection of any book, or register, or other document or record of any listed public company or a public company which intends to get its securities listed on any recognized stock exchange where the Board has reasonable grounds to believe that such company has been indulging in insider trading or fraudulent and unfair trade practices relating to securities market.

- While exercising the powers under the Act, the Board shall have the same powers as are vested in a civil court under the Code of Civil Procedure, 1908 (5 of 1908).

- The Board may, take any of the following measures:

- Suspend the trading of any security in a recognized stock exchange.

- Restrain persons from accessing the securities market and prohibit any person associated with securities market to buy, sell or deal in securities.

- Suspend any office-bearer of any stock exchange or self- regulatory organization from holding such position.

- Impound and retain the proceeds or securities in respect of any transaction which is under investigation. 
- Attach for a period not exceeding one month, one or more bank account or accounts of any intermediary or any person associated with the securities market in any manner involved in violation of any of the provisions of this Act, or the rules or the regulations made there under.

- Direct any intermediary or any person associated with the securities market in any manner not to dispose of or alienate an asset forming part of any transaction which is under investigation.

- The Board may take any of the measures in respect of any listed public company or a public company which intends to get its securities listed on any recognized stock exchange where the Board has reasonable grounds to believe that such company has been indulging in insider trading or fraudulent and unfair trade practices relating to securities market.

Objectives of the study:

1) To know the awareness level of SEBI Act among the investors in three districts namely Visakhapatnam, Vizianagaram and Srikakulam.

2) To know the level of awareness complaint mechanism available to investors

3) To identify the performance of investor protection guidelines set by SEBI

4) To identify the satisfaction level of investors about protection measures under taken by SEBI

5) To check the performance of investor education programs

\section{Review of Literature:}

The SEBI is a regulatory body which is eighteen years old and the capital market system is more than 100 years old. This matured capital market system requires monitoring rather than over-regulation. The SEBI should supervise this capital market system in such a manner that all sub-systems become self-regulatory organisations (SROs) gradually. The SEBI should lay down the boundaries within which these sub-systems should operate. Moreover, the fundamental infrastructure for regulation, disclosure, surveillance and trading are all in place. Hence, the SEBI should stop being pre-occupied with day-to-day regulations and become more of a visionary. The SEBI can ensure a free and fair market and take India into league of major global capital markets in the next round of reforms. To enable this, it has to thoroughly review its structure and functioning. The SEBI has to balance between the costs of regulation and market development. There should be cross-border cooperation between various regulators and between regulators and industry ${ }^{1}$.

While the data provide a quantitative measure of the work accomplished by SEBI, they do not measure its impact on the efficiency of the market. As Gokarn (1996) points out that exercise is complicated by the quick pace at which many of these developments have taken place as well as the number of other factors that affect the efficiency of the securities markets. Yet another aspect that is not addressed in this paper is the cost of regulation to issuers. The regulatory activity of SEBI imposes a cost on issuers. However, in the absence of an analysis that measures the impact of the regulation on the efficiency of the market, it is not possible to assess whether the cost incurred is justified by the benefits. Such an analysis is impeded by the paucity of relevant data. In other jurisdictions that SEBI draws upon for its work such as the UK or USA, cost-benefit justification is an essential aspect of the evaluation of the utility of regulation. A related and more basic concern relates to SEBI's approach to coming up with new regulations. Several of the provisions add to the cost of administration and compliance with the regulations. The requirement of having IPOs graded, minimum dilution, mandatory illiquidity on a part of the owner managers' holding are instances of provisions that add to the cost of administering and complying with the regulations. There appears to be no empirical justification for these requirements. On the contrary, there is some evidence in Khurshed, et al (2008) to suggest that the grading of IPOs does not affect the under-pricing of book-built IPOs.

On balance, however, the data suggest that SEBI has achieved considerable progress in terms of its oversight of the securities market both in quantitative and qualitative terms. In conclusion, the observation of High Level Committee on Financial Sector Reforms while recommending that the SEBI's role as a regulator be expanded is worth quoting here: "SEBI is ideally suited for filling these roles for several reasons. First, the equity market (both spot and derivatives) is India's most sophisticated and most liquid market; hence, SEBI's knowledge is rooted in the strongest market. Second, the legal foundations of SEBI are relatively recent, and they are less subject to legacy issues. Finally, the vigorous pace at which the SEBI Act and SC(R)A have been amended in the last decade - in response to the requirements of the equity market - has helped position SEBI to take on new challenges ${ }^{2} . "$

The SEBI has been operating now as the securities markets regulator for a decade and a half, and has appeared to have done a commendable task in upholding the mandate it was charged with, in a period of high growth and reasonably heightened levels of economic volatility. The principles based on which the entity was created has stood it in good stead. Some of these principles include clarity on the mandate it was to deliver on, non-interference from the government, statutory powers to issue Sub-ordinate legislation which can be noticed 
expeditiously to accommodate the rapid changes that takes place in the equities markets in India and the powers to enforce the regulatory mandate.

The credibility of SEBI as a regulator also appears to have been facilitated hugely by the creation of specialised courts with specialised domain knowledge that can rapidly review regulatory actions. In the process of ensuring that the markets develop in such a way that the objective of securities markets continue to be met, the legal processes at SEBI have also continued to evolve along the lines of higher levels of transparency of processes, clarity of actions and credibility of legal action.

In order that the regulator continues to evolve and bridge any gaps between current process and what the principles driving a good regulatory functioning would suggest, we suggest that SEBI continues to ne-tune the legal processes, particularly in enforcement, to achieve better levels of clarity on regulation and the legal process $^{3}$.

The enactment of the SEBI Act within the context of other statutes such as the Companies Act, Depositories Act and Securities Contracts Regulation Act has provided a strong regulatory framework for the Indian market. Subsequently much of the growth of the Indian market can be attributed to the robust processes for issuance, pricing, allotment and listing of securities enabled by SEBI. Strengthening SEBI's power in the investigative, administrative and legal aspects of enforcement would enable it to speedily address legal challenges such as those faced during dematerialization or disclosure requirements. In the future, SEBI should adopt more transparency to gain higher public confidence ${ }^{4}$.

\section{Research Methodology:}

We have designed a structured questionnaire and collected information directly from the investors among the three districts. This is a pilot study and we have analyzed the data collected from the respondents' through tabulation and observation.

\section{Secondary data:}

Some of the data was collected through SEBI annual reports and other published data. We have also referred peer reviewed Indian and international journals to supplement data required for the analysis.

\section{Data Analysis:}

1) Age wide classification of sample respondents

\begin{tabular}{|l|l|l|l|l|l|l|l|l|l|l|}
\hline S No & District & Sample & Less than 25 & $\%$ & 25 to35 & $\%$ & 35 to50 & $\%$ & Above 50 & $\%$ \\
\hline 1 & Srikakulam & 50 & 8 & $16 \%$ & 11 & $\begin{array}{l}22 \\
\%\end{array}$ & 27 & $\begin{array}{l}54 \\
\%\end{array}$ & 4 \\
\hline 2 & Vizianagaram & 50 & 4 & $8 \%$ & 25 & $\begin{array}{l}50 \\
\%\end{array}$ & 18 & $\begin{array}{l}36 \\
\%\end{array}$ & 3 \\
\hline 3 & Visakhapatnam & 50 & 5 & $10 \%$ & 33 & $\begin{array}{l}66 \\
\%\end{array}$ & 12 & $\begin{array}{l}24 \\
\%\end{array}$ & $6 \%$ & $0 \%$ \\
\hline & Total & 150 & 17 & $11 \%$ & 69 & $\begin{array}{l}46 \\
\%\end{array}$ & 57 & $\begin{array}{l}38 \\
\%\end{array}$ & 7 & $5 \%$ \\
\hline
\end{tabular}

Inference: It is observed that there is a significant difference between the overall age group responses to individual districts response. Both Vizianagaram and Vishakhapatnam have reported highest percentage of response from 25 to 35 age group than any other class, but whereas in Srikakulam it happened with 35 to 50 age group.

2) Gender wide classification of sample respondents

\begin{tabular}{|l|l|l|l|l|l|l|}
\hline S No & District & Sample & Male & Percent & Female & Percent \\
\hline 1 & Srikakulam & 50 & 34 & $68 \%$ & 16 & $32 \%$ \\
\hline 2 & Vizianagaram & 50 & 35 & $70 \%$ & 15 & $30 \%$ \\
\hline 3 & Visakhapatnam & 50 & 35 & $70 \%$ & 15 & $30 \%$ \\
\hline & Total & 150 & 119 & $69 \%$ & 31 & $31 \%$ \\
\hline
\end{tabular}

Inference: There is near equal percentage of response from both male (69\%) and female (31\%) irrespective to the districts. 
1) Qualification wide classification of sample respondents

\begin{tabular}{|l|l|l|l|l|l|l|l|l|l|l|}
\hline S No & District & Sample & Graduation & $\%$ & PG & $\%$ & UG & $\%$ & Others & $\%$ \\
\hline 1 & Srikakulam & 50 & 21 & $42 \%$ & 23 & $46 \%$ & 5 & $10 \%$ & 1 & $2 \%$ \\
\hline 2 & Vizianagaram & 50 & 12 & $24 \%$ & 28 & $56 \%$ & 8 & $16 \%$ & 2 & $4 \%$ \\
\hline 3 & Visakhapatnam & 50 & 18 & $36 \%$ & 24 & $48 \%$ & 7 & $14 \%$ & 1 & $2 \%$ \\
\hline & Total & 150 & 43 & $29 \%$ & 58 & $39 \%$ & 24 & $16 \%$ & 25 & $17 \%$ \\
\hline
\end{tabular}

Inference: It is observed that most of the people who are investing in stock markets are PGs. Next to PG, Graduates are investing in stock markets. In Srikakulam district, there are near equal percentage of investors are from PG and Graduation.

4) Occupation wide description of sample respondents

\begin{tabular}{|c|c|c|c|c|c|c|c|c|c|c|c|c|}
\hline $\begin{array}{l}\mathrm{S} \\
\text { No }\end{array}$ & District & Sample & Govt.Sec & $\%$ & $\begin{array}{l}\text { Private } \\
\text { Sec }\end{array}$ & $\%$ & Business & $\%$ & Agriculture & $\%$ & Others & $\%$ \\
\hline 1 & Srikakulam & 50 & 11 & $22 \%$ & 18 & $36 \%$ & 5 & $10 \%$ & 5 & $10 \%$ & 11 & $22 \%$ \\
\hline 2 & Vizianagaram & 50 & 17 & $34 \%$ & 7 & $14 \%$ & 20 & $40 \%$ & 2 & $4 \%$ & 4 & $8 \%$ \\
\hline 3 & Visakhapatnam & 50 & 3 & $6 \%$ & 29 & $58 \%$ & 15 & $30 \%$ & 0 & $0 \%$ & 3 & $6 \%$ \\
\hline & Total & 150 & 31 & $21 \%$ & 54 & $36 \%$ & 40 & $27 \%$ & 7 & $5 \%$ & 18 & $12 \%$ \\
\hline
\end{tabular}

Inference: The private sector employees' participation in stock market investments is more than any other kind. But typically in Vizianagaram district, business people are investing more than private sector employees with significant difference. It is also observed that agriculture based people are nil towards stock market investment in Visakhapatnam district.

5) Family income wide classification of sample respondents

\begin{tabular}{|c|c|c|c|c|c|c|c|c|c|c|c|c|}
\hline $\begin{array}{l}\mathrm{S} \\
\text { No }\end{array}$ & District & $\begin{array}{l}\text { Samp } \\
\text { le }\end{array}$ & $\begin{array}{c}\text { Up to } \\
\text { Rs } \\
10000 \\
\text { PM }\end{array}$ & $\%$ & $\begin{array}{l}1000 \\
1 \text { to } \\
2500 \\
0\end{array}$ & $\%$ & $\begin{array}{l}25001 \\
\text { to } \\
40000\end{array}$ & $\%$ & $\begin{array}{l}4000 \\
1 \text { to } \\
7500 \\
0\end{array}$ & $\%$ & $\begin{array}{l}75001 \text { an } \\
\text { above }\end{array}$ & $\%$ \\
\hline 1 & $\begin{array}{l}\text { Srikakula } \\
\mathrm{m}\end{array}$ & 50 & 4 & $8 \%$ & 10 & $\begin{array}{l}20 \\
\%\end{array}$ & 20 & $\begin{array}{l}40 \\
\% \\
\end{array}$ & 15 & $\begin{array}{l}30 \\
\%\end{array}$ & 1 & $\begin{array}{l}2 \\
\% \\
\end{array}$ \\
\hline 2 & $\begin{array}{l}\text { Vizianaga } \\
\text { ram }\end{array}$ & 50 & 2 & $4 \%$ & 8 & $\begin{array}{l}16 \\
\%\end{array}$ & 15 & $\begin{array}{l}30 \\
\%\end{array}$ & 25 & $\begin{array}{l}50 \\
\%\end{array}$ & 0 & $\begin{array}{l}0 \\
\%\end{array}$ \\
\hline 3 & $\begin{array}{l}\text { Visakhap } \\
\text { atnam }\end{array}$ & 50 & 6 & $\begin{array}{l}12 \\
\%\end{array}$ & 11 & $\begin{array}{l}22 \\
\%\end{array}$ & 13 & $\begin{array}{l}26 \\
\% \\
\end{array}$ & 18 & $\begin{array}{l}36 \\
\% \\
\end{array}$ & 2 & $\begin{array}{l}4 \\
\% \\
\end{array}$ \\
\hline & Total & 150 & 22 & $\begin{array}{l}15 \\
\%\end{array}$ & 42 & $\begin{array}{l}28 \\
\%\end{array}$ & 48 & $\begin{array}{l}32 \\
\%\end{array}$ & 32 & $\begin{array}{l}21 \\
\%\end{array}$ & 6 & $\begin{array}{l}4 \\
\%\end{array}$ \\
\hline
\end{tabular}

Inference: It is observed that higher income people are away from stock investments among all the districts. Half of the percentage investors are investing in stock markets whose income class is 40001 to 75000 than any other class.

\begin{tabular}{|c|c|c|c|c|c|c|c|c|c|c|}
\hline $\begin{array}{l}\mathrm{S} \\
\text { No }\end{array}$ & District & $\begin{array}{l}\text { Sampl } \\
\text { e }\end{array}$ & $\begin{array}{l}\text { Less than } \\
6 \text { months }\end{array}$ & $\%$ & $\begin{array}{l}11 \text { Yr to } \\
2 \text { Yrs }\end{array}$ & $\%$ & $\begin{array}{l}2 \text { Yrs to } 3 \\
\text { Yrs }\end{array}$ & $\%$ & $\begin{array}{l}\text { More than } \\
3 \text { Yrs }\end{array}$ & $\%$ \\
\hline 1 & Srikakulam & 50 & 0 & $\begin{array}{l}0 \\
\%\end{array}$ & 11 & $\begin{array}{l}22 \\
\%\end{array}$ & 30 & $\begin{array}{l}60 \\
\%\end{array}$ & 9 & $18 \%$ \\
\hline 2 & Vizianagaram & 50 & 0 & $\begin{array}{l}0 \\
\%\end{array}$ & 17 & $\begin{array}{l}34 \\
\%\end{array}$ & 18 & $\begin{array}{l}36 \\
\%\end{array}$ & 15 & $30 \%$ \\
\hline 3 & Visakhapatnam & 50 & 0 & $\begin{array}{l}0 \\
\%\end{array}$ & 15 & $\begin{array}{l}30 \\
\%\end{array}$ & 15 & $\begin{array}{l}30 \\
\%\end{array}$ & 20 & $40 \%$ \\
\hline & Total & 150 & 0 & $\begin{array}{l}0 \\
\%\end{array}$ & 43 & $\begin{array}{l}29 \\
\%\end{array}$ & 63 & $\begin{array}{l}42 \\
\%\end{array}$ & 44 & $29 \%$ \\
\hline
\end{tabular}

Inference: In the recent scenario, people are not attracted by stock markets reporting zero percent investors less than 6 months presence in stock investments. Experienced investors are observed in Visakhapatnam district. 


\begin{tabular}{|c|c|c|c|c|c|c|c|c|c|c|}
\hline $\begin{array}{l}\text { S } \\
\text { No }\end{array}$ & District & Sample & $\begin{array}{l}\text { By Stock } \\
\text { Broker }\end{array}$ & $\%$ & Online & $\%$ & $\begin{array}{l}\text { Over } \\
\text { mobile }\end{array}$ & $\%$ & $\begin{array}{l}\text { Any } \\
\text { Othe } \\
\mathrm{r}\end{array}$ & $\%$ \\
\hline 1 & Srikakulam & 50 & 18 & $36 \%$ & 25 & $50 \%$ & 1 & $2 \%$ & 6 & $12 \%$ \\
\hline 2 & Vizianagaram & 50 & 26 & $52 \%$ & 10 & $20 \%$ & 0 & $0 \%$ & 14 & $28 \%$ \\
\hline \multirow[t]{2}{*}{3} & Visakhapatnam & 50 & 26 & $52 \%$ & 21 & $42 \%$ & 3 & $6 \%$ & 0 & $0 \%$ \\
\hline & Total & 150 & 70 & $47 \%$ & 56 & $37 \%$ & 4 & $3 \%$ & 20 & $13 \%$ \\
\hline
\end{tabular}

Inference: Still many investors are dependent on stock broker to make investments in stock. In Vizianagaram other modes of investments are significant and mobile usage is nil for stock investment.

3) Do you aware of Securities and Exchange Board of India (SEBI) Investor Protection Act,

1992 ?

\begin{tabular}{|l|l|l|l|l|l|l|l|l|}
\hline S No & District & Sample & Yes & $\%$ & No & $\%$ & Not Sure & $\%$ \\
\hline 1 & Srikakulam & 50 & 40 & $80 \%$ & 10 & $20 \%$ & 0 & $0 \%$ \\
\hline 2 & Vizianagaram & 50 & 30 & $60 \%$ & 5 & $10 \%$ & 15 & $30 \%$ \\
\hline 3 & Visakhapatnam & 50 & 38 & $76 \%$ & 12 & $24 \%$ & 0 & $0 \%$ \\
\hline & Total & 150 & 108 & $72 \%$ & 27 & $18 \%$ & 15 & $10 \%$ \\
\hline
\end{tabular}

Inference: Though majority of investors are known about SEBI Act, investors In Vizianagaram district are significantly not known to SEBI Act.

5) Does SEBI have any control over the risk of illiquidity (Not possible to sell shares)?

\begin{tabular}{|l|l|l|l|l|l|l|l|l|}
\hline S No & District & Sample & Yes & $\%$ & No & $\%$ & $\begin{array}{l}\text { Not } \\
\text { Sure }\end{array}$ & $\%$ \\
\hline 1 & Srikakulam & 50 & 23 & $46 \%$ & 16 & $32 \%$ & 11 & $22 \%$ \\
\hline 2 & Vizianagaram & 50 & 21 & $42 \%$ & 5 & $10 \%$ & 24 & $48 \%$ \\
\hline 3 & Visakhapatnam & 50 & 18 & $36 \%$ & 29 & $58 \%$ & 3 & $6 \%$ \\
\hline & Total & 150 & 62 & $41 \%$ & 50 & $33 \%$ & 38 & $25 \%$ \\
\hline
\end{tabular}

Inference: Significantly the investors in Vizianagaram district are not aware bout the SEBI control about risk of illiquidity of shares.

6) Are you receiving any other information from the company apart from the annual body meeting information?
\begin{tabular}{|l|l|l|l|l|l|l|l|l|}
\hline S No & District & Sample & Yes & $\%$ & No & $\%$ & Not Sure & $\%$ \\
\hline 1 & Srikakulam & 50 & 39 & $78 \%$ & 11 & $22 \%$ & 0 & $0 \%$ \\
\hline 2 & Vizianagaram & 50 & 21 & $42 \%$ & 24 & $48 \%$ & 5 & $10 \%$ \\
\hline 3 & Visakhapatnam & 50 & 18 & $36 \%$ & 23 & $46 \%$ & 9 & $18 \%$ \\
\hline & Total & 150 & 78 & $52 \%$ & 58 & $39 \%$ & 14 & $9 \%$ \\
\hline
\end{tabular}

Inference: Though overall conclusion states that fifty percent of investors are receiving company information and the other fifty percent are not or not sure, in Srikakulam district, more than $75 \%$ are receiving information and the others are not.

(7) Does the investor can comply with SEBI even if he/she does not receive dividend after 30days of dividend announcement?

\begin{tabular}{|l|l|l|l|l|l|l|l|l|}
\hline S No & District & Sample & Yes & $\%$ & No & $\%$ & Not Sure & $\%$ \\
\hline 1 & Srikakulam & 50 & 35 & $70 \%$ & 9 & $18 \%$ & 6 & $12 \%$ \\
\hline 2 & Vizianagaram & 50 & 24 & $48 \%$ & 8 & $16 \%$ & 18 & $36 \%$ \\
\hline 3 & Visakhapatnam & 50 & 26 & $52 \%$ & 9 & $18 \%$ & 15 & $30 \%$ \\
\hline
\end{tabular}


Inference: Investors in Srikakulam district have more awareness on dividend issues and less uncertain also.

8) Are you aware that there is no need to pay tax on Dividend payment?

\begin{tabular}{|l|l|l|l|l|l|l|l|l|}
\hline S No & District & Sample & Yes & $\%$ & No & $\%$ & Not Sure & $\%$ \\
\hline 1 & Srikakulam & 50 & 19 & $38 \%$ & 19 & $38 \%$ & 12 & $24 \%$ \\
\hline 2 & Vizianagaram & 50 & 8 & $16 \%$ & 11 & $22 \%$ & 31 & $62 \%$ \\
\hline 3 & Visakhapatnam & 50 & 38 & $76 \%$ & 6 & $12 \%$ & 6 & $12 \%$ \\
\hline & Total & 150 & 65 & $43 \%$ & 36 & $24 \%$ & 49 & $33 \%$ \\
\hline
\end{tabular}

Inference: Comparatively investors in Vizianagaram district have less awareness about tax issues on dividend payment.

\begin{tabular}{|c|c|c|c|c|c|c|c|c|}
\hline S No & District & Sample & Yes & $\%$ & No & $\%$ & Not Sure & $\%$ \\
\hline 1 & Srikakulam & 50 & 19 & $38 \%$ & 19 & $38 \%$ & 12 & $24 \%$ \\
\hline 2 & Vizianagaram & 50 & 10 & $20 \%$ & 25 & $50 \%$ & 15 & $30 \%$ \\
\hline 3 & Visakhapatnam & 50 & 32 & $64 \%$ & 12 & $24 \%$ & 6 & $12 \%$ \\
\hline & Total & 150 & 61 & $41 \%$ & 56 & $37 \%$ & 33 & $22 \%$ \\
\hline
\end{tabular}

Inference: Comparatively investors in Vizianagaram district have less awareness about other issues on dividend payment.

10) Are you aware about facilities provided by Depository Participants?

\begin{tabular}{|l|l|l|l|l|l|l|l|l|}
\hline S No & District & Sample & No & $\%$ & Yes & $\%$ & Not Sure & $\%$ \\
\hline 1 & Srikakulam & 50 & 20 & $40 \%$ & 10 & $20 \%$ & 20 & $40 \%$ \\
\hline 2 & Vizianagaram & 50 & 16 & $32 \%$ & 7 & $14 \%$ & 27 & $54 \%$ \\
\hline 3 & Visakhapatnam & 50 & 6 & $12 \%$ & 38 & $76 \%$ & 6 & $12 \%$ \\
\hline & Total & 150 & 42 & $28 \%$ & 55 & $37 \%$ & 53 & $35 \%$ \\
\hline
\end{tabular}

Inference: There are different outcomes are identified from among the investors in three districts in connection with awareness level of facilities provided by Depository Participants.

11) Are you aware about share transfer facility?

\begin{tabular}{|l|l|l|l|l|l|l|l|l|}
\hline $\begin{array}{l}\text { S } \\
\text { No }\end{array}$ & District & Sample & No & $\%$ & Yes & $\%$ & Not Sure & $\%$ \\
\hline 1 & Srikakulam & 50 & 14 & $28 \%$ & 28 & $56 \%$ & 8 & $16 \%$ \\
\hline 2 & Vizianagaram & 50 & 11 & $22 \%$ & 22 & $44 \%$ & 17 & $34 \%$ \\
\hline 3 & Visakhapatnam & 50 & 10 & $20 \%$ & 32 & $64 \%$ & 8 & $16 \%$ \\
\hline & Total & 150 & 35 & $23 \%$ & 82 & $55 \%$ & 33 & $22 \%$ \\
\hline
\end{tabular}

Inference: Average investor aware about share transfer facility.

12) Are you aware about changes in share transfer charges that are charged by your broker?

\begin{tabular}{|l|l|l|l|l|l|l|l|l|}
\hline S No & District & Sample & No & $\%$ & Yes & $\%$ & Not Sure & $\%$ \\
\hline 1 & Srikakulam & 50 & 9 & $18 \%$ & 32 & $64 \%$ & 9 & $18 \%$ \\
\hline 2 & Vizianagaram & 50 & 11 & $22 \%$ & 31 & $62 \%$ & 8 & $16 \%$ \\
\hline 3 & Visakhapatnam & 50 & 23 & $46 \%$ & 9 & $18 \%$ & 18 & $36 \%$ \\
\hline & Total & 150 & 43 & $29 \%$ & 72 & $48 \%$ & 35 & $23 \%$ \\
\hline
\end{tabular}

Inference: Average investor aware about share transfer charges that are charged by their brokers.

13) Are you aware about share transfer charges fixed by SEBI?

\begin{tabular}{|l|l|l|l|l|l|l|l|l|}
\hline $\begin{array}{l}\text { S } \\
\text { No }\end{array}$ & District & Sample & No & $\%$ & Yes & $\%$ & Not Sure & $\%$ \\
\hline 1 & Srikakulam & 50 & 22 & $44 \%$ & 15 & $30 \%$ & 13 & $26 \%$ \\
\hline 2 & Vizianagaram & 50 & 11 & $22 \%$ & 11 & $22 \%$ & 28 & $56 \%$ \\
\hline 3 & Visakhapatnam & 50 & 38 & $76 \%$ & 3 & $6 \%$ & 9 & $18 \%$ \\
\hline & Total & 150 & 71 & $47 \%$ & 29 & $19 \%$ & 50 & $33 \%$ \\
\hline
\end{tabular}

Inference: Investors in Vizianagaram district are not sure about SEBI share transfer charges and investors in remaining districts are not aware about the same.

14) Have you ever faced any problems regarding DEMAT account? [a] No [b] Yes

\begin{tabular}{|l|l|l|l|l|l|l|}
\hline S No & District & Sample & No & $\%$ & Yes & $\%$ \\
\hline 1 & Srikakulam & 50 & 36 & $72 \%$ & 14 & $28 \%$ \\
\hline 2 & Vizianagaram & 50 & 45 & $90 \%$ & 5 & $10 \%$ \\
\hline 3 & Visakhapatnam & 50 & 50 & $100 \%$ & 0 & $0 \%$ \\
\hline & Total & 150 & 131 & $87 \%$ & 19 & $13 \%$ \\
\hline
\end{tabular}

Inference: Though most of the investors don't have problems regarding DEMAT A/C 
Among the three districts, in Srikakulam district investors some problems.

15) Are you aware about share transaction charges by your broker?

\begin{tabular}{|l|l|l|l|l|l|l|l|l|}
\hline S No & District & Sample & No & $\%$ & Yes & $\%$ & Not Sure & $\%$ \\
\hline 1 & Srikakulam & 50 & 0 & $0 \%$ & 39 & $78 \%$ & 11 & $22 \%$ \\
\hline 2 & Vizianagaram & 50 & 2 & $4 \%$ & 45 & $90 \%$ & 3 & $6 \%$ \\
\hline 3 & Visakhapatnam & 50 & 3 & $6 \%$ & 41 & $82 \%$ & 6 & $12 \%$ \\
\hline & Total & 150 & 5 & $3 \%$ & 125 & $83 \%$ & 20 & $13 \%$ \\
\hline
\end{tabular}

Inference: Still some investors are not sure about share transaction charges fixed by their brokers.

\begin{tabular}{|c|c|c|c|c|c|c|c|c|}
\hline S No & District & Sample & No & $\%$ & Yes & $\%$ & Not Sure & $\%$ \\
\hline 1 & Srikakulam & 50 & 5 & $10 \%$ & 25 & $50 \%$ & 20 & $40 \%$ \\
\hline 2 & Vizianagaram & 50 & 14 & $28 \%$ & 27 & $54 \%$ & 9 & $18 \%$ \\
\hline \multirow[t]{2}{*}{3} & Visakhapatnam & 50 & 26 & $52 \%$ & 18 & $36 \%$ & 6 & $12 \%$ \\
\hline & Total & 150 & 45 & $30 \%$ & 70 & $47 \%$ & 35 & $23 \%$ \\
\hline
\end{tabular}

Inference: Most of the investors are aware about service tax charges over share transactions. But investors in Visakhapatnam district are not aware these charges.

17) Are you aware about IPO charges fixed by SEBI?

\begin{tabular}{|l|l|l|l|l|l|l|l|l|}
\hline S No & District & Sample & No & $\%$ & Yes & $\%$ & Not Sure & $\%$ \\
\hline 1 & Srikakulam & 50 & 35 & $70 \%$ & 10 & $20 \%$ & 5 & $10 \%$ \\
\hline 2 & Vizianagaram & 50 & 39 & $78 \%$ & 8 & $16 \%$ & 3 & $6 \%$ \\
\hline 3 & Visakhapatnam & 50 & 32 & $64 \%$ & 4 & $8 \%$ & 14 & $28 \%$ \\
\hline & Total & 150 & 106 & $71 \%$ & 22 & $15 \%$ & 22 & $15 \%$ \\
\hline
\end{tabular}

Inference: Most of the investors are not aware about IPO charges fixed by SEBI

18) Are you receiving invitations to participate in annual body meeting from the companies whom you have shares?

\begin{tabular}{|l|l|l|l|l|l|l|l|l|l|l|}
\hline S No & District & Sample & No & $\%$ & Yes & $\%$ & Not Sure & $\%$ & Not aware & $\%$ \\
\hline 1 & Srikakulam & 50 & 8 & $16 \%$ & 20 & $40 \%$ & 14 & $28 \%$ & 8 & $16 \%$ \\
\hline 2 & Vizianagaram & 50 & 11 & $22 \%$ & 28 & $56 \%$ & 11 & $22 \%$ & 0 & $0 \%$ \\
\hline 3 & Visakhapatnam & 50 & 3 & $6 \%$ & 29 & $58 \%$ & 15 & $30 \%$ & 3 & $6 \%$ \\
\hline & Total & 150 & 22 & $15 \%$ & 77 & $51 \%$ & 40 & $27 \%$ & 11 & $7 \%$ \\
\hline
\end{tabular}

Inference: Though most of the investors are receiving invitations to participate in annual body meeting the same percentage of investors are not sure or not aware or not receiving invitations for the same.

\begin{tabular}{|c|c|c|c|c|c|c|c|c|c|c|}
\hline S No & District & Sample & No & $\%$ & Yes & $\%$ & Not Sure & $\%$ & Not aware & $\%$ \\
\hline 1 & Srikakulam & 50 & 14 & $28 \%$ & 27 & $54 \%$ & 0 & $0 \%$ & 9 & $18 \%$ \\
\hline 2 & Vizianagaram & 50 & 17 & $34 \%$ & 17 & $34 \%$ & 11 & $22 \%$ & 5 & $10 \%$ \\
\hline 3 & Visakhapatnam & 50 & 6 & $12 \%$ & 32 & $64 \%$ & 6 & $12 \%$ & 6 & $12 \%$ \\
\hline & Total & 150 & 37 & $25 \%$ & 76 & $51 \%$ & 17 & $11 \%$ & 20 & $13 \%$ \\
\hline
\end{tabular}

Inference: Most of the investors are receiving annual reports from the companies.

20) Are you aware that SEBI is organizing financial education workshops free?

\begin{tabular}{|l|l|l|l|l|l|l|l|l|}
\hline S No & District & Sample & Yes & $\%$ & No & $\%$ & Not Sure & $\%$ \\
\hline 1 & Srikakulam & 50 & 2 & $4 \%$ & 45 & $90 \%$ & 3 & $6 \%$ \\
\hline 2 & Vizianagaram & 50 & 1 & $2 \%$ & 47 & $94 \%$ & 2 & $4 \%$ \\
\hline 3 & Visakhapatnam & 50 & 2 & $4 \%$ & 45 & $90 \%$ & 3 & $6 \%$ \\
\hline & Total & 150 & 5 & $3 \%$ & 137 & $91 \%$ & 8 & $5 \%$ \\
\hline
\end{tabular}

Inference: All of the investors are not aware about free workshops organized by SEBI. 
21) Have you ever faced problems about delisting of the companies in which you own the shares?

\begin{tabular}{|l|l|l|l|l|l|l|l|l|l|l|}
\hline S No & District & Sample & No & $\%$ & Yes & $\%$ & Not Sure & $\%$ & Not aware & $\%$ \\
\hline 1 & Srikakulam & 50 & 19 & $38 \%$ & 11 & $22 \%$ & 11 & $22 \%$ & 9 & $18 \%$ \\
\hline 2 & Vizianagaram & 50 & 13 & $26 \%$ & 27 & $54 \%$ & 10 & $20 \%$ & 0 & $0 \%$ \\
\hline 3 & Visakhapatnam & 50 & 6 & $12 \%$ & 23 & $46 \%$ & 18 & $36 \%$ & 3 & $6 \%$ \\
\hline & Total & 150 & 38 & $25 \%$ & 61 & $41 \%$ & 39 & $26 \%$ & 12 & $8 \%$ \\
\hline
\end{tabular}

Inference: Though many of the investors are not having any problems about delisting of companies but also the same percentage of investors are not sure about the problems.

22) How an investor can lodge a complaint with SEBI?

\begin{tabular}{|c|c|c|c|c|c|c|c|c|c|c|}
\hline S No & District & Sample & $\begin{array}{l}\text { www.scores.g } \\
\text { ov.in }\end{array}$ & $\%$ & $\begin{array}{l}\text { Direct } \\
\text { visit to } \\
\text { SEBI }\end{array}$ & $\%$ & $\begin{array}{l}\text { Letter to } \\
\text { SEBI }\end{array}$ & $\%$ & $\begin{array}{l}\text { All of } \\
\text { the } \\
\text { above }\end{array}$ & $\%$ \\
\hline 1 & Srikakulam & 50 & 12 & $\begin{array}{l}24 \\
\% \\
\end{array}$ & 12 & $24 \%$ & 26 & $52 \%$ & 0 & 0 \\
\hline 2 & Vizianagaram & 50 & 22 & $\begin{array}{l}44 \\
\%\end{array}$ & 18 & $36 \%$ & 10 & $20 \%$ & 0 & 0 \\
\hline 3 & Visakhapatnam & 50 & 23 & $\begin{array}{l}46 \\
\% \\
\end{array}$ & 3 & $6 \%$ & 24 & $48 \%$ & 0 & 0 \\
\hline & Total & 150 & 57 & $\begin{array}{l}38 \\
\% \\
\end{array}$ & 33 & $22 \%$ & 60 & $40 \%$ & 0 & 0 \\
\hline
\end{tabular}

Inference: Many of the investors are lodging their complaints with a letter to SEBI and direct visit to SEBI.

\begin{tabular}{|c|c|c|c|c|c|c|c|c|}
\hline S No & District & Sample & No & $\%$ & Yes & $\%$ & Not Sure & $\%$ \\
\hline 1 & Srikakulam & 50 & 6 & $12 \%$ & 25 & $50 \%$ & 19 & $38 \%$ \\
\hline 2 & Vizianagaram & 50 & 11 & $22 \%$ & 17 & $34 \%$ & 22 & $44 \%$ \\
\hline \multirow[t]{2}{*}{3} & Visakhapatnam & 50 & 12 & $24 \%$ & 26 & $52 \%$ & 12 & $24 \%$ \\
\hline & Total & 150 & 29 & $19 \%$ & 68 & $45 \%$ & 53 & $35 \%$ \\
\hline
\end{tabular}

Inference: Many of the investors are aware about facilities provided by depository participants.

24) Have you lodged any complaint at SEBI? [a] No [ b] Yes .
\begin{tabular}{|l|l|l|l|l|l|l|}
\hline S No & District & Sample & No & $\%$ & Yes & $\%$ \\
\hline 1 & Srikakulam & 50 & 39 & $78 \%$ & 11 & $22 \%$ \\
\hline 2 & Vizianagaram & 50 & 43 & $86 \%$ & 7 & $14 \%$ \\
\hline 3 & Visakhapatnam & 50 & 44 & $88 \%$ & 6 & $12 \%$ \\
\hline & Total & 150 & 126 & $84 \%$ & 24 & $16 \%$ \\
\hline
\end{tabular}

Inference: Many investors in these three districts have not lodged any complaint so far.

\section{Research Findings:}

- It is observed that there is a significant difference between the overall age group responses to individual districts response. Both Vizianagaram and Vishakhapatnam have reported highest percentage of response from 25 to 35 age group than any other class, but whereas in Srikakulam it happened with 35 to 50 age group.

- There is near equal percentage of response from both male $(69 \%)$ and female $(31 \%)$ irrespective to the districts.

- It is observed that most of the people who are investing in stock markets are PGs. Next to PG, Graduates are investing in stock markets. In Srikakulam district, there are near equal percentage of investors are from PG and Graduation.

- The private sector employees' participation in stock market investments is more than any other kind. But typically in Vizianagaram district, business people are investing more than private sector employees with significant difference. It is also observed that agriculture based people are nil towards stock market investment in Visakhapatnam district.

- It is observed that higher income people are away from stock investments among all the districts. Half of the percentage investors are investing in stock markets whose income class is 40001 to 75000 than any other class.

- In the recent scenario, people are not attracted by stock markets reporting zero percent investors less than 6 months presence in stock investments. Experienced investors are observed in Visakhapatnam district. The percentage of investors is nearly $20 \%$ in urban areas while it is much lower $(6 \%)$ in rural India ${ }^{5}$. The year 2012-13, when retail investors pulled Rs 66,000 crore out from equities, wasn't an exception. This is a 10year-old trend, not, as widely believed, from only the Lehman crisis ${ }^{6}$. 
- Still many investors are dependent on stock broker to make investments in stock. In Vizianagaram other modes of investments are significant and mobile usage is nil for stock investment.

- Though majority of investors are known about SEBI Act, investors In Vizianagaram district are significantly not known to SEBI Act.

- Significantly the investors in Vizianagaram district are not aware bout the SEBI control about risk of illiquidity of shares.

- Though overall conclusion states that fifty percent of investors are receiving company information and the other fifty percent are not or not sure, in Srikakulam district, more than $75 \%$ are receiving information. Disclosure of Accounting Treatment: Where in the preparation of financial statements, a treatment different from that prescribed in an Accounting Standard has been followed, the fact shall be disclosed in the financial statements, together with the management's explanation as to why it believes such alternative treatment is more representative of the true and fair view of the underlying business transaction in the Corporate Governance Report ${ }^{7}$.

- Investors in Srikakulam district have more awareness on dividend issues and less uncertain also.

- Comparatively investors in Vizianagaram district have less awareness about tax issues on dividend payment.

- Comparatively investors in Vizianagaram district have less awareness about other issues on dividend payment.

- There are different outcomes are identified from among the investors in three districts in connection with awareness level of facilities provided by Depository Participants.

- Average investor aware about share transfer facility.

- Average investor aware about share transfer charges that are charged by their brokers.

- Investors in Vizianagaram district are not sure about SEBI share transfer charges and investors in remaining districts are not aware about the same.

- Though most of the investors don't have problems regarding DEMAT A/C among the three districts, in Srikakulam district investors some problems.

- Still some investors are not sure about share transaction charges fixed by their brokers.

- Most of the investors are aware about service tax charges over share transactions. But investors in Visakhapatnam district are not aware these charges.

- Most of the investors are not aware about IPO charges fixed by SEBI. It is observed that, in recent times, SEBI has, retails investors limit increased to Rs. 2,00,000 from Rs. 1,00,000 in Initial Public Offererings(IPOs). In recent times SEBI has taken a drastic decision for reduction of IPOs' period from 21 days to12 days ${ }^{8}$ (IPOs issue-opening and listing-period)

- Though most of the investors are receiving invitations to participate in annual body meeting the same percentage of investors are not sure or not aware or not receiving invitations for the same.

- Most of the investors are receiving annual reports from the companies.

- All of the investors are not aware about free workshops organized by SEBI.

- Though many of the investors are not having any problems about delisting of companies but also the same percentage of investors are not sure about the problems. SEBI, if not $100 \%$, than for sure it has been near to $100 \%$ success as far as the protections of the investors are concerned. As we have been that via different guidelines it had made it sure that no stone remains unturned in the path of the mission of protecting the investors.

- Many of the investors are lodging their complaints with a letter to SEBI and direct visit to SEBI.

- Many of the investors are aware about facilities provided by depository participants.

- Many investors in these three districts have not lodged any complaint so far.

\section{Conclusion}

The enactment of the SEBI Act within the context of other statutes such as the Companies Act, Depositories Act and Securities Contracts Regulation Act has provided a strong regulatory framework for the Indian market. Subsequently much of the growth of the Indian market can be attributed to the robust processes for issuance, pricing, allotment and listing of securities enabled by SEBI. Strengthening SEBI's power in the investigative, administrative and legal aspects of enforcement would enable it to speedily address legal challenges such as those faced during dematerialization or disclosure requirements. In the future, SEBI should adopt more transparency to gain higher public confidence. 


\section{References:}

[1]. SHAIK ABUDL MAJEEB PASHA*; R.VAMSI KRISHNA**; V. HEMANTHA GOPI KIRAN***

[2]. *Professor, Nimra College of Business Management, Jupudi, Vijayawada, Andhra Pradesh, India. **Assistant Professor, Nimra College of Business Management, Jupudi, Vijayawada, Andhra Pradesh, India. ***M.B.A. Student, Nimra College of Business Management, Jupudi, Vijayawada, Andhra Pradesh, India. International Journal of Multidisciplinary Research, Vol.2 Issue 3, March 2012, ISSN 22315780

[3]. G Sabarinathan SEBI's Regulation of the Indian Securities Market: A Critical Review of the Major Developments VIKALPA • VOLUME 35 • NO 4 • OCTOBER - DECEMBER 2010

[4]. Dharmishta Raval, Improving the legal process in enforcement at SEBI Indira Gandhi Institute of Development Research, Mumbai April 2011

[5]. Kaushik Dhar, National Academy of Legal Studies and Research (NALSAR) University - NALSAR, working papers series, Secunderabad, March 2, 2012

[6]. http://www.economicsfanatic.com Saturday, May 12, 2012 - India, India Equity Markets

[7]. April 4, $2013 \mathrm{http}: / / w w w . b u s i n e s s-s t a n d a r d . c o m$

[8]. http://www.nseindia.com/getting_listed/content/clause_49.pdf

[9]. ZENITH International Journal of Multidisciplinary Research Vol.2 Issue 3, March 2012, ISSN 2231 5780. A STUDY ON ROLE OF SEBI IN INDIAN CAPITAL MARKET: AN EMPIRICAL ANALYSIS 